\title{
Variation in morpho-physiological, biochemical and molecular responses of two Eucalyptus species under short-term water stress
}

\author{
Sivanantham Amrutha ${ }^{1}$, Abdul Bari Muneera Parveen ${ }^{1}$, Muthusamy Muthupandi' ${ }^{1}$, \\ Veerasamy Sivakumar ${ }^{1}$, Raman Nautiyal ${ }^{2}$, Modhumita Ghosh Dasgupta ${ }^{1 *}$ \\ ${ }^{1}$ Institute of Forest Genetics and Tree Breeding, R. S. Puram, Coimbatore 641002, India \\ ${ }^{2}$ Indian Council of Forestry Research and Education, P. O. New Forest, Dehradun 248006, Uttarakhand, India
}

\begin{abstract}
The genus Eucalyptus occurs in a wide range of environmental conditions, including rainforests, subalpine, arid/semi-arid and moist temperate zones. It includes species with the capacity to cope with extremely low water potential. This study aims to screen water stress tolerance in two Eucalyptus species under nursery conditions. Inter-specific variation in morphological, physiological, biochemical and molecular parameters in two Eucalyptus species (E. tereticornis and E. camaldulensis) with contrasting levels of tolerance to progressive short term water-deprived condition was evaluated. Water stress reduced growth measured in terms of root:shoot ratio and specific leaf area (SLA), photosynthetic parameters, leaf water potential and relative water content (RWC) in both genotypes. Biochemical parameters including total sugars, phenol, phytohormones (indole acetic acid and abscisic acid) and proline were found to significantly increase during stress in both genotypes. Water responsive transcripts like osmotin and DREB/CBF registered significant expression variation in the two genotypes, suggesting their key role in regulating water stress tolerance in Eucalyptus.
\end{abstract}

Keywords: drought stress, leaf temperature, osmotin, sugars, transcription factors

\section{Introduction}

The genus Eucalyptus with over 900 species forms a dominant canopy of woodland ecosystems (Boland et al. 2006). The ecological range of Eucalyptus species encompasses high rainfall, temperate, semi arid and extreme arid conditions (Merchant et al. 2006). Several species belonging to the subgenus Symphyomyrtus are adapted to prolonged water deficit conditions, determining the species distribution (Adams 1996).

Eucalypts are widely introduced as a plantation crop due to their rapid growth, adaptability and superior wood properties for the paper and pulp industries. Eucalyptus grandis, E. urophylla, E. globulus, E. camaldulensis, and their hybrids account for $80 \%$ of plantations globally. Seven species, E. camaldulensis, E. grandis, E. globulus, E. pellita, E. tereticornis, E. urophylla and Corymbia citriodora, were reported to be suitable for Indian agro-climatic conditions and are widely planted in the subcontinent (Kallarackal and Somen 1997, Kallarackal et al. 2002).
The high potential productivity of Eucalyptus has resulted in the deployment of genetically improved planting stock in mono-specific plantations to maximize harvesting performance (Forrester et al. 2010). However, this practise renders the plantations vulnerable to abiotic and biotic stresses that affect establishment and growth (White et al. 2009). Further, the potential productivity in eucalypts is governed by stem growth, biomass allocation and water availability (Stape et al. 2008).

Response to water-deprived conditions in Eucalyptus species has been extensively studied. Significant changes in osmotic potential, gas-exchange parameters, cell turgor adjustment (White et al. 1996), stomatal function (Costa e Silva et al. 2004), chlorophyll and carotenoid contents (Michelozzi et al. 1995) in leaf tissues are reported during water-deprived conditions. Other parameters used to assess water stress tolerance included changes in leaf temperature, photosynthetic rate, leaf water potential, and transpiration rate (Dye 1996,

* Corresponding author e-mail: ghoshm@icfre.org 
Roden and Ball 1996, Rolando and Little 2003, Stokes 2004). Concurrently, reduction in plant growth (Chaves et al. 2003, Bedon et al. 2012), photosynthesis (Warren et al. 2007) and hormone production (Granda et al. 2011) have also been reported during water stress conditions.

The Institute of Forest Genetics and Tree Breeding, Coimbatore, India initiated its program on the genetic improvement of Eucalyptus in 1997 in association with CSIRO, Australia. Productive clones with superior pulping quality were tested under multi-environment conditions and subsequently released and deployed in plantation programs. In the present study two Eucalyptus species were evaluated for their response to water deficit conditions and variations in growth, physiological, biochemical and transcript expression patterns were documented to identify key parameters governing water stress tolerance in the species studied.

\section{Materials and methods}

\section{Plant material}

The two species used in the present study are second generation clones derived from the Eucalyptus breeding program implemented by the Institute of Forest Genetics and Tree Breeding, Coimbatore, India. Eucalyptus tereticornis (Et88) was selected from the seed production area established and maintained by the Institute at Pudukottai, Tamil Nadu, India. Eucalyptus camaldulensis (Ec226) is of Katherine, Northern Territory, provenance and was selected from the seed orchard at Satyavedu, Andhra Pradesh, India, which was established and maintained by the Institute. The selection of the genotypes in the present study was based on a preliminary phenotypic screening of 60 clones for water stress tolerance (data not shown). Eucalyptus camaldulensis (Ec226) was used as the susceptible genotype, while E. tereticornis (Et88) served as the tolerant genotype.

\section{Experiment design and water stress imposition}

Coppice cuttings of both species were rooted and maintained in polybags containing a soil mixture of Pallam soil, River sand and Red earth in the ratio of 2:1:0.5. The cuttings were fortified with Hoagland's media (Hoagland and Arnon $1950)$ supplemented to its field capacity (FC) $(30 \mathrm{~mL})$ on alternate days for a period of 5 days prior to being subjected to water stress conditions. Subsequently, six month old cuttings were transferred to a controlled environmental chamber and maintained at $32 \pm 3{ }^{\circ} \mathrm{C}$ with relative humidity at $70-80 \pm 5 \%$.

Fifteen ramets of each genotype were used for the study in a randomized design. Six ramets per genotype were subjected to a well-watered (WW) regime wherein the cuttings were watered to $100 \%$ FC every day, while nine ramets were subjected to progressive water stress (WS) regime. The stress treatment was initiated by complete water withdrawal for a period of 15 days and the soil moisture content was recorded everyday using a tensiometer. On day 6 when soil moisture content was $0.005 \pm 0.0011 \mathrm{MPa}$, the susceptible geno- type Ec226 showed symptoms of leaf curling and hence all parameters except root:shoot ratio were assessed on days 5 and 6 after stress imposition. The root:shoot ratio was documented on day 15 after the imposition of water stress treatment with soil moisture content of $0.0215 \pm 0.0017 \mathrm{MPa}$. All parameters were recorded in three randomly selected ramets and used as biological replicates.

\section{Physiological parameters}

Root:shoot ratio analysis of clones subjected to WW and WS conditions was conducted on oven dried samples after completion of the experiment on day 15 post stress imposition.

Specific leaf area (SLA) was determined from scanned images of 4-5 leaves and the area was determined using Image J software (Schindelin et al. 2015). Digital images of leaves (with ruler) were uploaded in the software and the scale was fixed using the 'set scale' option in the tool. Subsequently, under the option 'Image', colour threshold was adjusted to shade the leaf area followed by measuring the area using the Wand tool. SLA was calculated as area divided by dry weight determined by oven drying of leaf material at $45^{\circ} \mathrm{C}$ for 2 days and represented as $\mathrm{cm}^{-2} \mathrm{~g}^{-1}$ leaf dry weight (LDW).

The leaf surface temperature and chlorophyll content were measured on day 6 after initiation of stress, since complete leaf curling was recorded after day 6 of stress imposition in the susceptible genotype Ec226. Temperature was manually recorded in mature leaves each day between 11.00 a. m. -12.00 p. m. using an infrared thermometer (Gaby Instruments, India) at 3 zonal levels of the plant (apex, midlevel and basal zone). The ambient temperature of the chamber was also recorded.

Three fully expanded leaves of each ramet were selected for estimating the chlorophyll content. The chlorophyll content index (CCI) was recorded using the chlorophyll concentration meter MC-100 (Apogee Instruments Inc., UT, USA) for both the WW and WS regime.

Photosynthetic rate (A), stomatal conductance (gs), intercellular $\mathrm{CO}_{2}$ concentration $(\mathrm{Ci})$ and transpiration rate (E) were measured using an LCi-SD photosynthesis system (ADC BioScientific Ltd. UK). Measurements were taken between 10 a. m. to 12 p. m. in mature leaves on day 6 after imposition of stress in both WW and WS plants.

Relative water content of the leaf (\% RWC) was determined from detached leaf segments of $1-2 \mathrm{~cm}$ length and their fresh weight $(\mathrm{Fw})$ was recorded on day 6 after imposition of water stress. The leaf segments were placed in deionised water for a period of $4 \mathrm{~h}$ and turgid weight (Tw) was recorded. Subsequently, leaves were dried at $60^{\circ} \mathrm{C}$ overnight and dry weight was determined (Dw). RWC was estimated according to Morgan (1984) using the formula $100 \times(\mathrm{Fw}$ $\mathrm{Dw}) /(\mathrm{Tw}-\mathrm{Dw})$.

Mid-day leaf water potential $\left(\Psi_{\mathrm{w}}\right)$ was assessed from a single mature leaf from three different ramets using the PSY1 stem psychrometer (ICT International, Australia) on day 5 
after imposition of stress. The psychrometer chamber was vacuum fixed over the non-cuticularized leaf surface and water potential was measured in MPa.

\section{Biochemical parameters}

Leaf tissues from both clones subjected to WW and WS conditions were assayed for total phenols, flavonoids, total sugars, proline content, free ABA and IAA content. Leaves were collected from three ramets each for both conditions on day 6 after imposition of water stress and processed independently for biochemical estimation. Fifty mg of leaf tissues were ground in liquid nitrogen and subsequently used for biochemical assay. Total phenols were estimated using the protocol described by Malik and Singh (1980), while total sugars were quantified by anthrone method (Hedge and Hofreiter 1962). Total flavonoids were estimated by aluminium chloride method (Kiranmaiet et al. 2011). The phytohormones, ABA and IAA were estimated using the protocol described by Unyayar et al. (1996), while leaf proline was determined using the procedure described by Ábrahám et al. (2010).

\section{Expression profiling of water stress responsive transcripts}

Total RNA was isolated from the leaves of WW and WS plants of both genotypes on day 6 of stress imposition. Sin- gle leaves from three independent ramets were harvested for RNA isolation and maintained as three biological replicates. RNA was isolated using RNAqueous ${ }^{\circ}$-Micro Total RNA Isolation Kit (Thermo Scientific, USA). The concentration and purity of RNA were evaluated using NanoDrop ND-1000 UV-Vis Spectrophotometer (Thermo Scientific, USA). Approximately $1 \mu \mathrm{g}$ of total RNA was treated with DNAse I and used to synthesize the first strand CDNA with RevertAid MMuLV Reverse Transcriptase (Thermo Scientific, USA) following the manufacturer's protocol.

In the present study, 12 drought responsive transcripts were selected according to their role in water stress response. Transcripts from hormone signaling pathways (AR, GER3, LEA6); osmoprotectant pathways (GOLS2, SIP, OSM34); sucrose pathway (TPPB); antioxidant (GPX6); membrane intrinsic protein $(P I P)$ and drought related transcription factors ( $D R E B, C B F 1 c, C B F 2$ ) were selected. Transcript selection was based on an earlier study in E. grandis (Ghosh Dasgupta and Dharanishanthi 2017). The expression of PEG induced water stress responsive transcripts were analysed by quantitative real time (qRT-PCR ; On-line Suppl. Tab. 1). qRT- PCR was performed using ABI PRISM 7500 Step one plus Sequence Detection System (Applied Biosystems, USA) using the following program: one cycle of $95^{\circ} \mathrm{C}$ for $10 \mathrm{~min} ; 40$ cycles of $95^{\circ} \mathrm{C}$ for $15 \mathrm{~s}$ and $60^{\circ} \mathrm{C}$ for $1 \mathrm{~min}$. The qRT-PCR reactions $(10 \mu \mathrm{L})$ included $200 \mathrm{ng}$ of cDNA, 5.0 mL SYBR Green JumpStartTaq ReadyMix (Sigma, St. Louis,

Tab. 1. Effect of short-term progressive water stress on different parameters in Eucalyptus tereticornis (Et88) and Eucalyptus camaldulensis (Ec226). Data presented are mean of triplicate values \pm SD (standard deviation). WW - Well watered condition; WS - water stress condition. SLA - specific leaf area; LDW - leaf dry weight; CCI - chlorophyll content index; RWC - relative water content; ABA - abscisic acid; IAA - indole acetic acid; FW - fresh weight.

\begin{tabular}{|c|c|c|c|c|}
\hline \multirow{2}{*}{$\begin{array}{l}\text { Clone ID } \\
\text { Treatments }\end{array}$} & \multicolumn{2}{|c|}{ Et 88} & \multicolumn{2}{|c|}{ Ec 226} \\
\hline & WW & WS & WW & WS \\
\hline SLA $\left(\mathrm{cm}^{-2} \mathrm{~g}^{-1} \mathrm{LDW}\right)$ & $46.56 \pm 9.28$ & $45.09 \pm 7.99$ & $47.04 \pm 1.50$ & $43.47 \pm 4.58$ \\
\hline Root: shoot ratio & $0.42 \pm 0.06$ & $0.45 \pm 0.08$ & $0.76 \pm 0.4$ & $0.98 \pm 0.2$ \\
\hline Leaf temperature $\left({ }^{\circ} \mathrm{C}\right)$ & $30.70 \pm 0.70$ & $31.78 \pm 0.39$ & $30.52 \pm 0.69$ & $31.60 \pm 0.31$ \\
\hline CCI & $11.12 \pm 1.94$ & $13.36 \pm 1.69$ & $9.63 \pm 0.98$ & $15.61 \pm 1.50$ \\
\hline RWC (\%) & $82.78 \pm 2.68$ & $78.79 \pm 3.50$ & $76.09 \pm 3.35$ & $40.07 \pm 5.64$ \\
\hline$\Psi_{\mathrm{w}}(\mathrm{MPa})$ & $-2.34 \pm 0.57$ & $-4.25 \pm 0.05$ & $-1.68 \pm 0.26$ & $-2.94 \pm 0.08$ \\
\hline Transpiration rate $\left(\mathrm{mmol} \mathrm{m}^{-2} \mathrm{~s}^{-1}\right)$ & $0.85 \pm 0.09$ & $0.80 \pm 0.12$ & $0.82 \pm 0.14$ & $0.42 \pm 0.07$ \\
\hline Stomatal conductance $\left(\mathrm{cm} \mathrm{s}^{-1}\right)$ & $0.11 \pm 0.01$ & $0.10 \pm 0.02$ & $0.13 \pm 0.03$ & $0.06 \pm 0.02$ \\
\hline Photosynthetic rate $\left(\mu \mathrm{mol} \mathrm{m} \mathrm{m}^{-2} \mathrm{~s}^{-1}\right)$ & $22.39 \pm 4.84$ & $17.18 \pm 1.71$ & $21.21 \pm 11.8$ & $8.39 \pm 3.46$ \\
\hline Total carbohydrate $\left(\mathrm{mg} \mathrm{g}^{-1} \mathrm{FW}\right)$ & $2.04 \pm 0.23$ & $5.28 \pm 1.65$ & $4.23 \pm 3.05$ & $9.04 \pm 1.59$ \\
\hline Flavonoids ( $\left.\mathrm{mg} \mathrm{g}^{-1} \mathrm{FW}\right)$ & $7.83 \pm 1.58$ & $11.31 \pm 2.69$ & $11.28 \pm 0.43$ & $10.01 \pm 1.19$ \\
\hline Phenols (mg g $\left.{ }^{-1} \mathrm{FW}\right)$ & $0.40 \pm 0.14$ & $0.97 \pm 0.43$ & $0.67 \pm 0.01$ & $1.13 \pm 0.18$ \\
\hline Proline $\left(\mu \mathrm{mol} \mathrm{g}{ }^{-1} \mathrm{FW}\right)$ & $4.86 \pm 1.83$ & $9.03 \pm 3.89$ & $3.56 \pm 0.10$ & $8.44 \pm 5.76$ \\
\hline $\mathrm{ABA}\left(\mathrm{mg} \mathrm{g}^{-1} \mathrm{FW}\right)$ & $0.04 \pm 0.01$ & $0.09 \pm 0.06$ & $0.03 \pm 0.01$ & $0.06 \pm 0.00$ \\
\hline IAA $\left(\mathrm{mg} \mathrm{g}^{-1} \mathrm{FW}\right)$ & $0.29 \pm 0.18$ & $0.60 \pm 0.08$ & $0.24 \pm 0.15$ & $0.50 \pm 0.03$ \\
\hline
\end{tabular}


MO, USA), $200 \mathrm{nM}$ each of forward and reverse primer and $0.4 \mu \mathrm{L}$ of $20 \mathrm{mg} \mathrm{mL}^{-1} \mathrm{BSA}$. All reactions were conducted in three biological replicates. The melting curve was generated to ensure product specificity and to differentiate between the product and primer dimer. Actin related protein 3 (ARP3) was used as reference gene for normalization of data (Karpaga Raja Sundari and Ghosh Dasgupta 2012). The relative quantification value (RQ) was calculated using the formula $2^{-\Delta \Delta C T}$ (Livak and Schmittgen 2001) and the fold decrease was calculated as the reciprocal of the fold change (Peirson et al. 2003).

\section{Statistical analyses}

All parameters were determined for three independent ramets and the data was represented as mean \pm SD. Statistical analysis for morphological, physiological and biochemical parameters was performed using Statistica version 7.0. The effect of species, treatment and their interaction on all parameters was tested using Nested ANOVA. Ramets were nested within treatment and treated as random effect in analyses, while the water stress treatment and species were considered fixed factors. The post hoc test with Bonferroni correction was conducted when an effect was found to be significant.

In transcript expression studies, delta CT for WW and WS conditions across species were statistically analyzed using $t$-test implemented in GraphPad Prism ${ }^{\circ}$ version 7 and the difference between the conditions were considered statistically significant when $\mathrm{P}<0.05$.

\section{Results}

The effect of water stress on two species of Eucalyptus was evaluated and the variations in growth, physiological, biochemical and transcript expression were recorded in WW and WS conditions.

\section{Physiological parameters}

Percent leaf curling was recorded in both genotypes under WW and WS conditions. In tolerant genotype Et88, $5.71 \% \pm 0.48$ leaf curling was documented, while susceptible genotype Ec226 recorded 96\% \pm 2.71 leaf curling under WS conditions (Fig. 1).

The root:shoot ratio was variable between the genotypes and Ec226 showed a decrease in shoot growth upon stress imposition, while no difference was registered in Et88 (Tab. 1). SLA was recorded in both genotypes under WW and WS conditions and a marginal decrease was documented in Et88, while a decrease in SLA was recorded in Ec226 under WS conditions when compared to WW condition (Tab. 1).

Leaf temperature showed a marginal increase under WS condition in both genotypes tested, while CCI was found to increase in Ec226 under WS condition when compared to WW condition. An increase in CCI in clone Et 88 was also recorded (Tab. 1). Percent RWC was found to vary in both genotypes subjected to WS condition, where Ec226 showed a
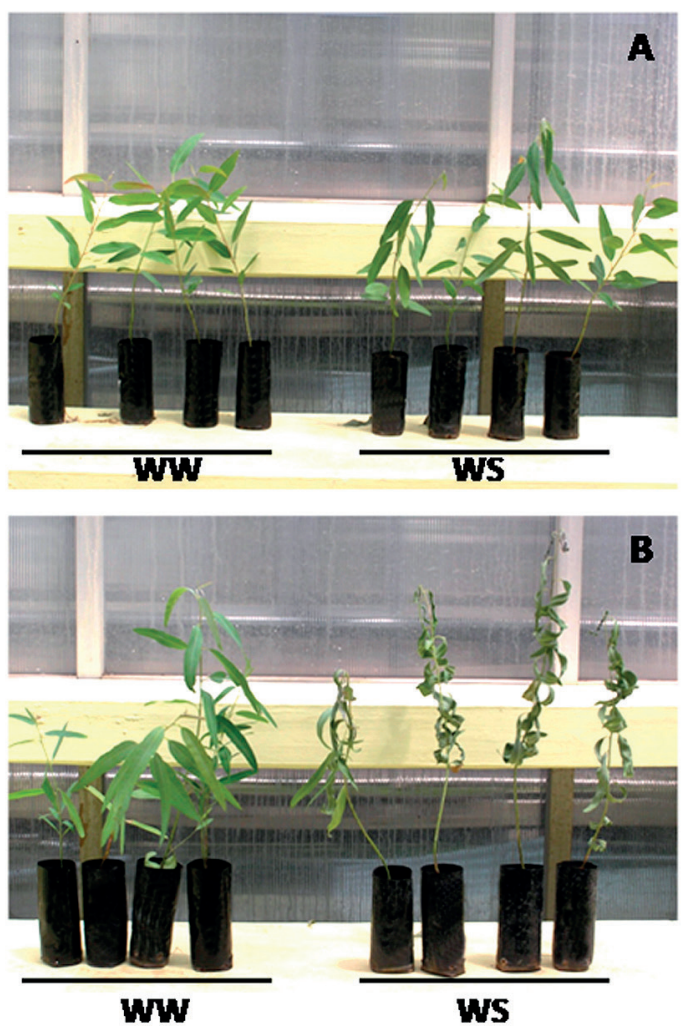

Fig. 1. Effect of progressive water stress in six month old rooted cuttings of (A) Eucalyptus tereticornis (Et88) and (B) Eucalyptus camaldulensis (Ec226); WW - Well watered condition; WS - Water deprived condition.

reduction in RWC in WS condition when compared to Et88 (Tab. 1). Mid-day leaf water potential $(\Psi \mathrm{w})$ was also found to reduce in WS condition in both Et88 and Ec226 when compared to WW condition (Tab. 1).

The photosynthetic parameters including transpiration rate, stomatal conductance and photosynthesis were recorded and a decrease in WS conditions in both genotypes was registered (Tab. 1). However, the decrease documented in Ec226 for transpiration rate, stomatal conductance and photosynthetic rate was high as compared to Et88 (Tab. 1).

\section{Biochemical parameters}

Six biochemical parameters including total sugars, flavonoids, phenols, proline, ABA and IAA content were recorded after 6 days of water stress imposition. All parameters were found to increase under WS condition in both genotypes except flavonoid content. Increase in total sugars was documented in clone Ec226 in WS condition as compared to the WW condition. A similar trend was observed in Et88 (Tab. 1). A decrease in the flavonoid content was recorded in Ec226 under WS condition, while it increased in Et88 (Tab. 1).

Significant differences across species and treatments were found in nested ANOVA for each measured parameter, at least in one of the factors (treatment or genotype or both) (Tab. 2). Leaf temperature and total phenol content were significantly different only for the treatment fac- 
Tab. 2. Statistical analysis of some morphological, physiological and biochemical parameters, in Eucalyptus tereticornis (Et88) and Eucalyptus camaldulensis (Ec226) exposed to water stress, across treatment and species. Df - degrees of freedom; SS - sum of squares; MS - mean of squares; $\mathrm{F}-\mathrm{F}$ value. Level of significance: ${ }^{\star} \mathrm{P}<0.01$, ${ }^{* *} \mathrm{P}<0.05$.

\begin{tabular}{|c|c|c|c|}
\hline Parameter & & Species & Treatment \\
\hline \multirow[t]{4}{*}{ Leaf temperature } & Df & 1 & 2 \\
\hline & SS & 0.11 & 3.40 \\
\hline & MS & 0.11 & 1.70 \\
\hline & $\mathrm{F}$ & 0.61 & $9.18^{\star}$ \\
\hline \multirow[t]{4}{*}{ RWC } & Df & 1 & 2 \\
\hline & SS & 1428.41 & 2043.93 \\
\hline & MS & 1428.41 & 1021.96 \\
\hline & $\mathrm{F}$ & $816.91^{*}$ & $583.95^{\star}$ \\
\hline \multirow{4}{*}{$\begin{array}{l}\text { Leaf water } \\
\text { potential }\end{array}$} & Df & 1 & 2 \\
\hline & SS & 2.90 & 7.80 \\
\hline & MS & 2.90 & 3.90 \\
\hline & $\mathrm{F}$ & $28.47^{\star}$ & $3.905^{*}$ \\
\hline \multirow{4}{*}{$\begin{array}{l}\text { Total } \\
\text { carbohydrates }\end{array}$} & Df & 1 & 2 \\
\hline & SS & 2658.55 & 5036.65 \\
\hline & MS & 2658.55 & 2518.32 \\
\hline & $\mathrm{F}$ & $7.24^{\star \star}$ & $6.85^{\star *}$ \\
\hline \multirow[t]{4}{*}{ Phenols } & $\mathrm{Df}$ & 1 & 2 \\
\hline & SS & 7.79 & 124.199 \\
\hline & MS & 7.79 & 62.099 \\
\hline & $\mathrm{F}$ & 0.58 & $4.61^{* *}$ \\
\hline \multirow[t]{4}{*}{ Root: Shoot } & Df & 1 & 2 \\
\hline & SS & 0.562 & 0.076 \\
\hline & MS & 0.562 & 0.038 \\
\hline & $\mathrm{F}$ & $8.32^{\star *}$ & 0.56 \\
\hline
\end{tabular}

tor, whereas significant differences for the species were recorded for root:shoot ratio. Significant differences in RWC, leaf water potential and total sugars content were found for both treatment and species.

\section{Expression profiling of water stress responsive transcripts}

Relative quantification (RQ) of twelve transcripts related to water deficit condition was determined using qRT-PCR in both genotypes. Osmotin (OSM34), dehydration responsive element binding proteins (DREB), C-repeat/DRE-binding factor (CBF1c and CBF2), glutathione peroxidase (GPX6), and raffinose synthase family protein $(S I P)$ showed significant up-regulation in Et88 when compared to Ec226 (Fig. 2). Maximum expression was recorded for OSM34 with Et88 registering a 54-fold increase compared to the 5-fold increase in Ec226. Further, Ec226 showed down regulation of all the transcripts profiled except OSM34 (6.31) and SIP (2.10). Down regulation of CBF2 (-22-fold), CBF1c (-11-fold) and DREB (-10-fold) was documented in Ec226 when compared to their expression level in Et88 which was up-regulated 20-fold, 28-fold and 15-fold, respectively (Fig. 2).

\section{Discussion}

A growing concern in commercial plantation programs has been the depletion in water resources and area of cultivation. Managing tree plantations to maximize wood production from available water resources is the critical parameter in tree breeding programs. In Eucalyptus, the concept of plantation water productivity $\left(\mathrm{PWP}_{\mathrm{WooD}}\right)$ is gaining importance in the provision of social license for wood production from plantations (White et al. 2014). Hence, several species of Eucalypts have been screened for their water stress tolerance and variations in response to low water potential are reported among species (Myers and Neales 1986) among provenances (Li 1998) and between clones (Pita and Pardos 2001). The inter- and intraspecific variation in response to changes in osmotic potential has been used as a selection criterion in genetic improvement programs in eucalypts (van der Moezel et al. 1991, Lemcoff et al. 1994).

The imposition of a water-deprived condition elicits multi-dimensional responses at morphological, physiological, biochemical and molecular levels (Granda et al. 2014). In Eucalyptus species and their hybrids, adjustments during water stress conditions are mediated by hormonal balance (Granda et al. 2011), variation in pigment content (Shvaleva et al. 2006, 2008), osmotic changes (Merchant et al.

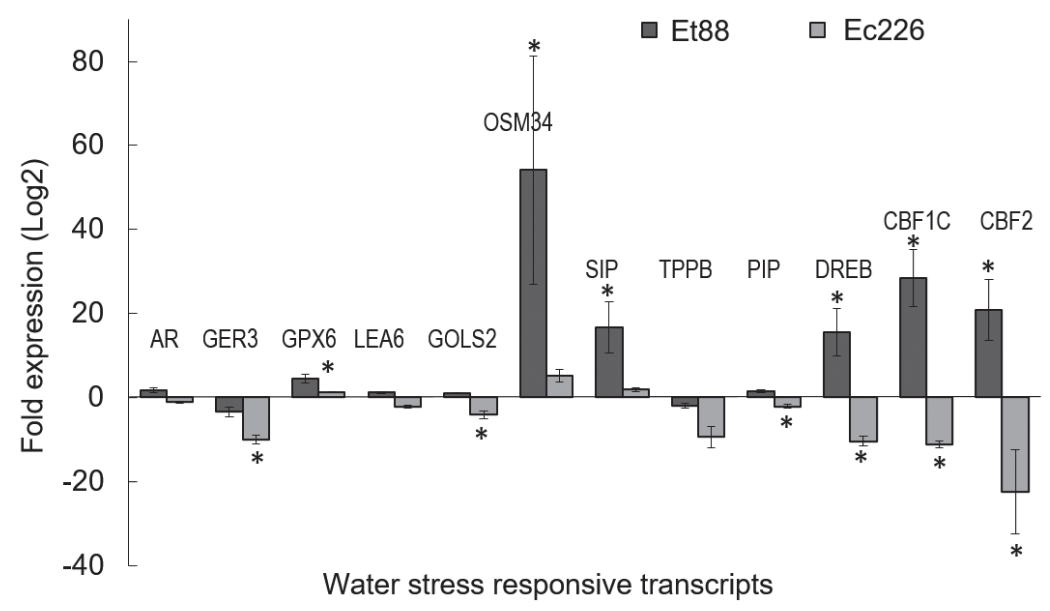

Fig. 2. Expression profiling of water stress responsive transcripts in leaves of Eucalyptus tereticornis (Et88) and Eucalyptus camaldulensis (Ec226). Values are mean of data from three biological replicates and the error bars represent SD. Gene IDs are given in On-line Suppl. Tab. 1. Asterisk indicates statistical significance between well watered and water stressed plants when $\mathrm{P}<0.05$. 
2006, Warren et al. 2007, Callister et al. 2008), photosynthesis adjustment (Warren et al. 2007) and growth modifications (Drew et al. 2009).

In general, water stress reduces growth rate in all species by modifying the biomass allocation in above and below ground tissues, which determines the morphological plasticity of the genotype (Maseda and Fernández 2016). In eucalypt species, reduction in growth and biomass under water stress conditions is reported in E. globulus (Costa e Silva et al. 2004, Correia et al. 2014, Coopman et al. 2008), E. camaldulensis (Maseda and Fernández 2016) and E. microtheca (Li 1998). In the present study, the genotype (Et88) showed marginal reduction in SLA and root:shoot ratio during stress imposition, while Ec226 documented significant reduction in both parameters, revealing that the tissue biomass was significantly reduced in Ec226 during stress conditions. The photosynthetically active leaf is the plant part that is critically affected by water limitation, which causes reduction in leaf emergence/expansion and shrinkage/curling (Burling et al. 2013, Scoffoni et al. 2014). The maintenance of balance between the areas involved in transpiration and absorption is a key determinant of survival and productivity as reported in E. globulus (Marron et al. 2003, Costa e Silva et al. 2004). Hence, reduction in leaf area during water stress condition is a response in all eucalypt species as reported in E. globulus (Costa e Silva et al. 2004, Maseda and Fernández 2016), E. camaldulensis (Lemcoff et al. 2002, Maseda and Fernández 2016) and E. microtheca (Susiluoto and Berninger 2007). Specific leaf area (SLA), which essentially describes the distribution of leaf biomass relative to area, is a major trait that correlates with whole plant growth (Cheng et al. 2016). It links carbon allocation and water status and thus is a critical parameter to assess soil moisture content (Pierce et al. 1994). In a recent study by Wellstein et al. (2017) in grasses and forbs from temperate and sub-Mediterranean ecosystems, it was hypothesized that phenotypic adjustments like SLA show variable response during short-term water stress and reduced SLA was associated with enhanced water use efficiency, while increased SLA indicated better growth performance. Hence, it was concluded that the differential response of SLA during drought conditions had to be interpreted according to the evolutionary history and environmental niche of the species. In agreement with this hypothesis, SLA was reported to decrease in E. globulus (Costa e Silva et al. 2004, Coopman et al. 2008) and increase in E. microtheca (Susiluoto and Berninger 2007) subsequent to stress imposition. In another study, no significant difference in SLA was reported in either E. camaldulensis or E. globulus seedlings during water stress (Maseda and Fernández 2016). In the present study, decrease in SLA was documented in both E. camaldulensis and E. tereticornis.

Leaf relative water content (RWC) is a key indicator of plant water status since it reflects the balance between water availability and transpiration rate (Lugojan and Ciulca 2011). The general trend of decrease in RWC during water-deprived conditions is documented in several eucalypt species including Eucalyptus camaldulensis (Maseda and Fernández 2016),
E. globulus (Pita and Pardos 2001), E. oblique, E. camaldulensis, E. rubida, E. polyanthemos, E. tricarpa, E. cladocalyx (Merchant et al. 2007) and Eucalyptus grandis $\times$ E. urophylla (Valadares et al. 2014). In the present study, a decrease in RWC was recorded in both genotypes but the level of reduction in Ec226 was significantly higher than in the clone Et88.

Accumulation of solutes like inorganic cations, organic acids, carbohydrates and free amino acids in response to water stress is generally reported in most plant species. They contribute to osmotic adjustments, thus maintaining a balance between sucrose synthesis and translocation (Morgan 1984, Akinci and Lösel 2012). Accumulation of soluble sugars in water deprived condition was reported in Eucalyptus species (Quick et al. 1992, Warren et al. 2011). It was also reported that E. camaldulensis and E. globulus from a 'mesic' environment underwent osmotic adjustments through increased sugar accumulation, while species from dry ('xeric') environments adjusted through increased concentration of quercitol (Merchant et al. 2006). In agreement with the earlier report, significant increase in the accumulation of total sugars was documented in both species, which occupy the 'mesic' environment.

Leaf/canopy temperature is an indicator of stomatal closure in response to soil water stress (Jones et al. 2009, 2002). During water stress condition, closure of stomata to maintain inner moisture content is an immediate response, resulting in increased leaf temperature, decreased transpiration and reduced photosynthesis, which adversely affect productivity (Luquet et al. 2003, Jones 2004, Feller 2016). Leaf temperature, water status and stomatal opening are closely connected (Valladares and Pearcy 1997, Feller 2006, Reynolds-Henne et al. 2010, Feller and Vaseva 2014, Teskey et al. 2015) and hence determination of leaf/canopy temperature as a measure of stomatal conductance using infrared thermometry was suggested as early as the 1980s (Jarvis 1981) to facilitate irrigation scheduling. It was reported that maintenance of lower leaf surface temperature in tolerant genotypes during stress conditions could lead to favourable water status, sustained transpiration and increased photosynthetic efficiency, resulting in improved yields ( $\mathrm{Ku}$ mar 2005). Using leaf temperature as drought index has been reported in potato (Gerhards et al. 2016), maize (Carroll et al. 2017), sorghum (Blume et al. 1978), wheat (Fischer et al. 1998, Talebi 2011), sugarcane (Silva et al. 2007), rice (Hirayama et al. 2006) and Firmiana platanifolia (Yu et al. 2015). However, in woody perennials leaf surface temperature as water stress index is of limited use. In a recent study on Pinus taeda and Populus deltoides $\times$ nigra, it was reported that leaf temperature had a direct effect on stomatal opening and an increase in leaf temperature was documented under water deprived condition in both genus irrespective of leaf morphology, xylem structure and physiology (Urban et al. 2017). The effect of leaf temperature on stomatal limitation to photosynthesis, intercellular $\mathrm{CO}_{2}$ concentration and net photosynthesis was demonstrated in the study. Similarly, an increase in leaf temperature was documented in both species in the present study. 
Transcriptional regulation of different pathways to maintain cellular homeostasis during water stress is well documented in plant systems (reviewed by Kaur and Asthir 2017). Several drought responsive genes including dehydrins, molecular chaperones, water channel proteins, transporters and biosynthetic enzymes for compatible solutes, growth regulators, enzymes that detoxify reactive oxygen species (Bartels and Sunkar 2005, Wang et al. 2006), transcription factors, protein phosphatases, phospholipid metabolic proteins and protein kinases (Shinozaki and Yamaguchi-Shinozaki 2007, Morran et al. 2011) are reported to play a pivotal role in cellular protection and stress alleviation. In Eucalyptus, extensive studies on morpho-physiological and biochemical response to water stress condition is reported, while molecular response is limited to transcriptome-wide response in E. globulus and E. cladocalyx (Spokevicius et al. 2017), E. camaldulensis (Thumma et al. 2012), E.alba hybrid and E. urophylla $\times$ E. grandis (Villar et al. 2011), and E. grandis (Ghosh Dasgupta and Dharanishanthi 2017). Osmotin and osmotinlike proteins (OLPs) are known to act as osmotic modulators by compartmentalizing solutes or regulating structural and metabolic alterations (Chowdhury et al. 2017). Biosynthesis of osmotin/OLPs was reported to depend on water status of cells, revealing their key role in osmotic adaptations (Weber et al. 2014, Patade et al. 2013). In transgenic systems, the role of osmotin as an osmoprotectant gene has been extensively reported in crops (reviewed by Khan et al. 2015, Das et al. 2011). Expression of osmotin during water deficit condition is reported in E. cladocalyx (Spokevicius et al. 2017) and E. grandis (Ghosh Dasgupta and Dharanishanthi 2017). In the present study, a significantly high expression of osmotin (OSM34) was registered in the clone Et88 (54-fold) as compared to Ec226 (fivefold), indicating that level of osmotin can act as an indicator in screening water-responsive genotypes. The role of transcription factors during dehydration stress has been extensively reviewed in crop plants (Nakashima et al. 2014, Singh and Laxmi 2015). In Eucalyptus, the major transcription factors which regulate water stress include zinc finger transcription factor family protein (Villar et al. 2011), MYB, NAC, ERF, HB12 (Thumma et al. 2012) and HSFs, DREB2A, DEAR3 (Ghosh Dasgupta and Dharanishanthi 2017). The ABA independent dehydration responsive element binding/C-repeat binding factors (DREB/CBF) belonging to the ethylene responsive factor/APETALA2 (ERF/

\section{References}

Ábrahám, E., Hourton-Cabassa, C., Erdei, L., Szabados, L., 2010: Methods for determination of proline in plants. Methods in Molecular Biology 639, 317-331.

Adams, M. A., 1996: Distribution of eucalypts in Australian landscapes: landforms, soils, fire and nutrition. In: Attiwill, P.M., Adams, M.A. (eds.), Nutrition of Eucalypts, 61-76. CSIRO Publishing, Melbourne.

Agarwal, P.K., Jha, B., 2010: Transcription factors in plants and ABA dependent and independent abiotic stress signalling. Biologia Plantarum 54, 201-212.

Akinci, S., Lösel, D.M., 2012: Plant water-stress response mechanisms. In: Rahman. M., Hasegawa, H. (eds.), Water Stress, 15-42. InTech, Rijeka.
AP2) family (Shinozaki and Yamaguchi-Shinozaki 2007) are major regulators governing drought response (Agarwal and Jha 2010). Genome-wide analysis in E. grandis revealed the presence of $17 D R E B 1 / C B F$ genes and 6 DREB2. Further, it was reported that $D R E B 1 / C B F$ was cold-inducible, while $D R E B 2$ was induced during water stress (Cao et al. 2015). In another study, ectopic expression of EguCBF1ab from $E$. gunnii in a Eucalyptus hybrid conferred drought and freezing tolerance (Navarro et al. 2011). An earlier study in E. globulus also revealed that drought tolerant genotypes exhibited better cold acclimation due to the accumulation of soluble sugars (Costa e Silva et al. 2009). In the present study, downregulation of $C B F 2, C B F 1 c$ and $D R E B$ in the clone Ec226, in contrast to their significant up-regulation in Et88, revealed the crucial role of $D R E B / C B F$ in conferring drought tolerance in eucalypts. In a similar study in Hevea, a strong correlation between fold expressions of $D R E B$ with drought tolerance was reported by Luke et al. (2015).

In the present study, several morpho-physiological, biochemical and molecular parameters were assessed to document their response during progressive water stress in two species of eucalypts with contrasting levels of tolerance. Leaf temperature, total phenol, root:shoot ratio, RWC, leaf water potential and total sugars showed significant variations across the two genotypes. Water responsive transcripts like osmotin and DREB/CBF registered significant expression variation in the two genotypes, indicating their key role in regulating water stress tolerance. Hence, the reported physiological (leaf temperature, RWC, leaf water potential and root:shoot ratio), biochemical (total sugars) and molecular (osmotin and DREB/CBF) parameters can be used as an explanatory variables in determining the selection of eucalypts under progressive short term water stress in nursery condition.

\section{Acknowledgements}

The authors acknowledge Department of Biotechnology, Government of India for funding the research work (project no. BT/PR10539/PBD/16/1064/2013). Funding support in the form of research fellowships was provided to SA, AMP and MM by the Department of Biotechnology, Government of India.

Bartels, D., Sunkar, R., 2005: Drought and salt tolerance in plants. Critical Reviews in Plant Sciences 24, 23-58.

Bedon, F., Villar, E., Vincent, D., Dupuy, J.W., Lomenech, A.M., Mabialangoma, A., Chaumeil, P., Barré, A., Plomion, C., Gion, J.M., 2012: Proteomic plasticity of two Eucalyptus genotypes under contrasted water regimes in the field. Plant Cell and Environment 35, 790-805.

Blume, A., Schertz, K.F., Toler, R.W., Welch, R.I., Rosenow, D.T., Johnson, J.W., Clark, L.E., 1978: Selection for drought avoidance in Sorghum using aerial infrared photography. Agronomy Journal 70, 472-477.

Boland, D.J., Brooker, M.I.H., Chippendale, G.M., Hall, N., Hyland, B.P.M., Johnson, R.D., Kleinig, D.A., McDonald, M.W., 
Turner, J.D., 2006: Forest trees of Australia. CSIRO Publishing, Melbourne.

Burling, K., Cerovic, Z.G., Cornic, G., Ducruet, J.M., Noga, G., Hunsche, M., 2013: Fluorescence-based sensing of drought induced stress in the vegetative phase of four contrasting wheat genotypes. Environmental and Experimental Botany 89, 5159 .

Callister, A.N., Arndt, S.K., Ades, P.K., Merchant, A., Rowell, D., Adams, M.A., 2008: Leaf osmotic potential of Eucalyptus hybrids responds differently to freezing and drought, with little clonal variation. Tree Physiology 28, 1297-1304.

Cao, P.B., Azar, S., SanClemente, H., Mounet, F., Dunand, C., Marque, G., Marque, C., Teulières, C., 2015: Genome-wide analysis of the AP2/ERF Family in Eucalyptus grandis: An intriguing over-representation of stress-responsive $D R E B 1 / C B F$ genes. PLoS ONE 10, e0121041.

Carroll, D.A., Hansen, N.C., Hopkins, B.G., De Jonge, K.C., 2017: Leaf temperature of maize and Crop Water Stress Index with variable irrigation and nitrogen supply. Irrigation Science 35, 549-560.

Chaves, M.M., Maroco, J.P., Pereira, J.S., 2003: Understanding plant responses to drought from genes to the whole plant. Functional Plant Biology 30, 239-264.

Cheng, J., Chu, P., Chen, D., Bai, Y., Niu, S., 2016: Functional correlations between specific leaf area and specific root length along a regional environmental gradient in Inner Mongolia grasslands. Functional Ecology 30, 985-997.

Chowdhury, S., Basu, A., Kundu, S., 2017: Overexpression of a new osmotin-like protein gene $(\operatorname{Sind} O L P)$ confers tolerance against biotic and abiotic stresses in sesame. Frontiers in Plant Science 8, 410.

Coopman, R., Jara, J., Bravo, L., Sáez, K., Mella, G., Escobar, R., 2008: Changes in morpho-physiological attributes of Eucalyptus globulus plants in response to different drought hardening treatments. Electronic Journal of Biotechnology 11, 30-39.

Correia, B., Pintó-Marijuan, M., Neves, L., Brossa, R., Dias, M.C., Costa, A., Castro, B.B., Araújo, C., Santos, C., Chaves, M.M. Pinto, G., 2014: Water stress and recovery in the performance of two Eucalyptus globulus clones: physiological and biochemical profiles. Physiologia Plantarum 150, 580-592.

Costa e Silva, F., Shvaleva, A., Broetto, F., Ortuno, M.F., Rodrigues, M.L., Almeida, M.H., Chaves, M.M., Pereira, J.S., 2009: Acclimation to short-term low temperatures in two Eucalyptus globulus clones with contrasting drought resistance. Tree Physiology 29, 77-86.

Costa e Silva, F., Shvaleva, A., Maroco, J.P., Almeida, M.H., Chaves, M.M., Pereira, J.S., 2004: Responses to water stress in two Eucalyptus globulus clones differing in drought tolerance. Tree Physiology 24, 1165-1172.

Das, M., Chauhan, H., Chhibbar, A., Rizwanul Haq, Q.M., Khurana, P., 2011: High-efficiency transformation and selective tolerance against biotic and abiotic stress in mulberry, Morus indica $\mathrm{cv}$. K2, by constitutive and inducible expression of tobacco osmotin. Transgenic Research 20, 231-246.

Drew, D.M., Downes, G.M., O'Grady, A.P., Read, J., Worledge, D., 2009: High resolution temporal variation in wood properties in irrigated and nonirrigated Eucalyptus globulus. Annals of Forest Science 66, 406

Dye, P.J., 1996: Response of Eucalyptus grandis trees to soil water deficits. Tree Physiology 16, 233-238.

Feller, U., 2006: Stomatal opening at elevated temperature: an under estimated regulatory mechanism. General and Applied Plant Physiology, special issue, 19-31.

Feller, U., 2016: Drought stress and carbon assimilation in a warming climate: Reversible and irreversible impacts. Journal of Plant Physiology 203, 84-94.
Feller, U., Vaseva, I.I., 2014: Extreme climatic events: impacts of drought and high temperature on physiological processes in agronomically important plants. Frontiers in Environmental Science 2, 39.

Fischer, R.A., Rees, D., Sayre, K.D., Lu, Z-M., Condon, A.G., Saavedra, A.L., 1998: Wheat yield progress associated with higher stomatal conductance and photosynthetic rate, and cooler canopies. Crop Science 38, 1467-1475.

Forrester, D.I., Theiveyanathan, S., Collopy, J.J., Marcar, N.E., 2010: Enhanced water use efficiency in a mixed Eucalyptus globulus and Acacia mearnsii plantation. Forest Ecology and Management 259, 1761-1770.

Gerhards, M., Rock, G., Schlerf, M., Udelhoven, T., 2016: Water stress detection in potato plants using leaf temperature, emissivity, and reflectance. International Journal of Applied Earth Observations and Geoinformation 53, 27-39.

Ghosh Dasgupta, M., Dharanishanthi, V., 2017: Identification of PEG-induced water stress responsive transcripts using co-expression network in Eucalyptus grandis. Gene 627, 393-407.

Granda, V., Cuesta, C., Alvarez, R., Ordás, R., Centeno, M.L., Rodríguez, A., Majada, J.P., Fernández, B., Feito, I., 2011: Rapid responses of $\mathrm{C} 14$ clone of Eucalyptus globulus to root drought stress: Time-course of hormonal and physiological signalling. Journal of Plant Physiology 168, 661-670.

Granda, V., Delatorre, C., Cuesta, C., Centeno, M.L., Fernández, B., Rodríguez, A., Feito, I., 2014: Physiological and biochemical responses to severe drought stress of nine Eucalyptus globulus clones: a multivariate approach. Tree Physiology 34, 778-786.

Hedge, J.E., Hofreiter, B.T., 1962: Carbohydrate Chemistry 17. Whistler, R.L., Be Miller, J.N. (eds.), Academic Press, New York.

Hirayama, M., Wada, Y., Nemoto, H., 2006: Estimation of drought tolerance based on leaf temperature in upland rice breeding. Breeding Science 56, 47-54.

Hoagland, D.R., Arnon, D.I., 1950: The water-culture method for growing plants without soil. California Agricultural Experiment Station, Berkeley.

Jarvis, P.G., Mansfield, T.A., 1981: Stomatal physiology. Cambridge University Press, Cambridge.

Jones, H.G., 2004: Application of thermal imaging and infrared sensing in plant physiology and ecophysiology. Advances in Botanical Research 41, 107-163.

Jones, H.G., Serraj, R., Loveys, B.R., Xiong, L.Z., Wheaton, A., Price, A.H., 2009: Thermal infrared imaging of crop canopies for the remote diagnosis and quantification of plant responses to water stress in the field. Functional Plant Biology 36, 978-989.

Jones, H.G., Stoll, M., Santos, T., de Sousa, C., Chaves, M.M., Grant, O.M., 2002: Use of infrared thermography for monitoring stomatal closure in the field: application to grapevine. Journal of Experimental Botany 53, 2249-2260.

Kallarackal, J., Somen, C.K., 1997: Water use by Eucalyptus tereticornis stands of differing density in southern India. Tree Physiology 17, 195-203.

Kallarackal, J., Somen, C.K., Rajesh, N., 2002: Studies on water use of six tropical Eucalypt species in Kerala. In: Bagchi, S.K. Varghese, M., Siddappa (eds.), Recent eucalypt research in India, 94-115. Institute of Forest Genetics and Tree Breeding, Coimbatore.

Karpaga Raja Sundari, B., Ghosh Dasgupta, M., 2012: Selection and validation of reference genes for real-time qRT-PCR normalization in different tissues of Eucalyptus tereticornis. Silvae Genetica 61, 221-300.

Kaur, G., Asthir, B., 2017: Molecular responses to drought stress in plants. Biologia Plantarum 61, 201-209. 
Khan, M.S., Ahmad, D., Khan, M.A., 2015: Utilization of genes encoding osmoprotectants in transgenic plants for enhanced abiotic stress tolerance. Electronic Journal of Biotechnology $18,257-266$.

Kiranmai, M., Mahendra Kumar, C.B., Ibrahim, M., 2011: Comparison of total flavonoid content of Azadirachta indica root bark extracts prepared by different methods of extraction. Research Journal of Pharmaceutical, Biological and Chemical Sciences 2, 254-261.

Kumar, D., 2005: Breeding for drought resistance. In: Ashraf, M., Harris, P.J.C., (eds.), Abiotic stresses: plant resistance through breeding and molecular approaches, 145-175. The Haworth Press, New York.

Lemcoff, J.H., Guarnaschelli, A.B., Garau, A.M., Basciauli, M.E., Ghersa, C.M., 1994: Osmotic adjustment and its use as a selection criterion in Eucalyptus seedlings. Canadian Journal of Forest Research 24, 2404-2408.

Lemcoff, J.H., Guarnaschelli, A.B., Garau, A.M., Prystupa, P., 2002: Elastic and osmotic adjustments in rooted cuttings of several clones of Eucalyptus camaldulensis Dehnh. from southeastern Australia after a drought. Flora 197, 134-142.

Li, C.Y., 1998: Some aspects of leaf water relations in four provenances of Eucalyptus microtheca seedlings. Forest Ecology and Management 111, 303-308.

Livak, K.J., Schmittgen, T.D., 2001: Analysis of relative gene expression data using real-time quantitative PCR and the 2-DDCT method. Methods 25, 402-408.

Lugojan, C., Ciulca, S., 2011: Evaluation of relative water content in winter wheat. Journal of Horticulture, Forestry and Biotechnology 5, 173-177.

Luke, L.P., Mohamed Sathik, M.B., Thomas, M., Kuruvilla, L., Sumesh, K.V., Annamalainathan, K., 2015: Quantitative expression analysis of drought responsive genes in clones of $\mathrm{He}$ vea with varying levels of drought tolerance. Physiology and Molecular Biology of Plants 21, 179-186.

Luquet, D., Begue, A., Vidal, A., Clouvel, P., Dauzat, J., Olioso, A., Gu, X.F., Tao, Y., 2003: Using multidirectional thermography to characterize water status of cotton. Remote Sensing of Environment $84,411-421$.

Malik, C.P., Singh, M.B., 1980: Plant enzymology and histo-enzymology. Kalyani Publishers, New Delhi.

Marron, N., Dreyer, E., Boudouresque, E., Delay, D., Petit, J.M., Delmotte, F.M., Brignolas, F., 2003: Impact of successive drought and re-watering cycles on growth and specific leaf area of two Populus $\times$ canadensis (moench) clones, 'Dorskamp' and 'Luisa_Avanzo'. Tree Physiology 23, 1225-1235.

Maseda, P.H., Fernández, R.J., 2016: Growth potential limits drought morphological plasticity in seedlings from six Eucalyptus provenances. Tree Physiology 36, 243-251.

Merchant, A., Callister, A., Arndt, S., Tausz, M., Adams, M., 2007: Contrasting physiological responses of six Eucalyptus species to water deficit. Annals of Botany 100, 1507-1515.

Merchant, A., Tausz, M., Arndt, S.K., Adams, M.A., 2006: Cyclitols and carbohydrates in leaves and roots of 13 Eucalyptus species suggest contrasting physiological responses to water deficit. Plant Cell and Environment 29, 2017-2029.

Michelozzi, M., Johnson, J.D., Warrag, E.I., 1995: Response of ethylene and chlorophyll in two Eucalyptus clones during drought. New Forests 9, 197-204.

Morgan, J.M., 1984: Osmoregulation and water stress in higher plants. Annual Review of Plant Physiology 35, 299-319.

Morran, S., Eini, O., Pyvovarenko, T., Parent, B., Singh, R., Ismagul, A., Eliby, S., Shirley, N., Langridge, P., Lopato, S., 2011: Improvement of stress tolerance of wheat and barley by modulation of expression of DREB/CBF factors. Plant Biotechnology Journal 9, 230-249.
Myers, B.A., Neales, T.F., 1986: Osmotic adjustment, induced by drought, in seedlings of three Eucalyptus species. Australian Journal of Plant Physiology 13, 597-603.

Nakashima, K., Yamaguchi-Shinozaki, K., Shinozaki, K., 2014: The transcriptional regulatory network in the drought response and its crosstalk in abiotic stress responses including drought, cold, and heat. Frontiers in Plant Science 5, 170.

Navarro, M., Ayax, C., Martinez, Y., Laur, J., El Kayal, W., Marque, C., Teulières, C., 2011: Two EguCBF1 genes overexpressed in Eucalyptus display a different impact on stress tolerance and plant development. Plant Biotechnology Journal 9, 50-63.

Patade, V.Y., Khatri, D., Kumari, M., Grover, A., Gupta, S.M., Ahmed, Z., 2013: Cold tolerance in osmotin transgenic tomato (Solanum lycopersicum L.) is associated with modulation in transcript abundance of stress responsive genes. Springerplus 2, 117.

Peirson, S.N., Butler, J.N., Foster, R.G., 2003: Experimental validation of novel and conventional approaches to quantitative real-time PCR data analysis. Nucleic Acids Research 31, e73.

Pierce, L.L., Running, S.W., Walker, J., 1994: Regional-scale relationships of leaf-area index to specific leaf-area and leaf nitrogen-content. Ecological Applications 4, 313-321.

Pita, P., Pardos, J.A., 2001: Growth, leaf morphology, water use and tissue water relations of Eucalyptus globulus clones in response to water deficit. Tree Physiology 21, 599-607.

Quick, W.P., Chaves, M.M., Wendler, R., David, M., Rodrigues, M.L., Passaharinho, J.A., Pereira, J.S., Adcock, M.D., Leegood, R.C., Stitt, M., 1992: The effect of water stress on photosynthetic carbon metabolism in four species grown under field conditions. Plant, Cell and Environment 15, 25-35.

Reynolds-Henne, C.E., Langenegger, A., Mani, J., Schenk, N., Zumsteg, A., Feller, U., 2010: Interactions between temperature, drought and stomatal opening in legumes. Environmental and Experimental Botany 68, 37-43.

Roden, J.S., Ball, M.C., 1996: The effect of elevated $\left[\mathrm{CO}_{2}\right]$ on growth and photosynthesis of two Eucalyptus species exposed to high temperatures and water deficits. Plant Physiology 111, 909-919.

Rolando, C.A., Little, K.M., 2003: Using chlorophyll fluorescence to determine stress in Eucalyptus grandis seedlings. Southern African Forestry Journal 197, 5-12.

Schindelin, J., Rueden, C.T., Hiner, M.C., Eliceiri, K.W., 2015: The Image ecosystem: An open platform for biomedical image analysis. Molecular Reproduction and Development 82, 518-529.

Scoffoni, C., Vuong, C., Diep, S., Cochard, H., Sack, L., 2014: Leaf shrinkage with dehydration: Coordination with hydraulic vulnerability and drought tolerance. Plant Physiology 164, 17721788.

Shinozaki, K., Yamaguchi-Shinozaki, K., 2007: Gene networks involved in drought stress response and tolerance. Journal of Experimental Botany 58, 221-227.

Shvaleva, A.L., Costa e Silva, F., Breia, E., Jouve, J., Hausman, J.F., Almeida, M.H., Maroco, J. P., Rodrigues, M.L., Pereira, J.S., Chaves, M.M., 2006: Metabolic responses to water deficit in two Eucalyptus globulus clones with contrasting drought sensitivity. Tree Physiology 26, 239-248.

Shvaleva, A.L., Costa e Silva, F., Scotti, P., Oufir, M., Hausman, J.F., Cedric, G., Ramos, P., Almeida, M.H., Rodrigues, M.L., Pereira, J.S., Chaves, M.M., 2008: Physiological and biochemical responses to low non-freezing temperature of two Eucalyptus globulus clones differing in drought resistance. Annals of Forest Science 65, 204.

Silva, M.A., Jifon, J.L., DaSilva, J.A.G., Sharma, V., 2007: Use of physiological parameters as fast tools to screen for drought tolerance in sugarcane. Brazilian Journal of Plant Physiology 19, 193-201. 
Singh, D., Laxmi, A., 2015: Transcriptional regulation of drought response: a tortuous network of transcriptional factors. Frontiers in Plant Science 6, 895.

Spokevicius, A.V., Tibbits, J., Rigault, P., Nolin, M.A., Müller, C., Merchant, A., 2017: Medium term water deficit elicits distinct transcriptome responses in Eucalyptus species of contrasting environmental origin. BMC Genomics 18, 284.

Stape, J.L., Binkley, D., Ryan, M.G., 2008: Production and carbon allocation in a clonal Eucalyptus plantation with water and nutrient manipulations. Forest Ecology and Management 255, 920-930.

Stokes, V., 2004: Assessingwater use in plants: An introduction and guide to methods of measurement. Scottish Forestry 58, 13-19.

Susiluoto, S., Berninger, F., 2007: Interactions between morphological and physiological drought responses in Eucalyptus microtheca. Silva Fennica 41, 221-233.

Talebi, R., 2011: Evaluation of chlorophyll content and canopy temperature as indicators for drought tolerance in durum wheat (Triticum durum Desf.). Australian Journal of Basic and Applied Sciences 5, 1457-1462.

Teskey, R., Wertin, T., Bauweraerts, I., Ameye, M., McGuire, M.A., Steppe, K., 2015: Responses of tree species to heat waves and extreme heat events. Plant Cell and Environment 38, 16991712.

Thumma, B.R., Sharma, N., Southerton, S.G., 2012: Transcriptome sequencing of Eucalyptus camaldulensis seedlings subjected to water stress reveals functional single nucleotide polymorphisms and genes under selection. BMC Genomics 13, 364.

Unyayar, S., Topcuoglu, S.F., Unyayar, A., 1996: A modified method for extraction and identification of Indole-3-Acetic Acid (IAA), Gibberellic Acid ( $\mathrm{GA}_{3}$ ), Abscisic Acid (ABA) and zeatin produced by Phanerochaete chrysosporium ME446. Bulgarian Journal of Plant Physiology 22, 105-110.

Urban, J., Ingwers, M.W., McGuire, M.A., Teskey, R.O., 2017: Increase in leaf temperature opens stomata and decouples net photosynthesis from stomatal conductance in Pinus taeda and Populus deltoides $\times$ nigra. Journal of Experimental Botany 68, 1757-1767.

Valadares, J., Paul, N.F.D., Paula, R.C.D., 2014: Physiological changes in eucalyptus hybrids under different irrigation regimes. Revista Ciencia Agronomica 45, 805-814.

Valladares, F., Pearcy, R.W., 1997: Interactions between water stress, sunshade acclimation, heat tolerance and photoinhibition in the sclerophyll Heteromeles arbutifolia. Plant Cell and Environment 20, 25-36.
Van der Moezel, P.G., Pearcepinto, G.V.N., Bell, D.T., 1991: Screening for salt and waterlogging tolerance in Eucalyptus and $\mathrm{Me}$ laleuca species. Forest Ecology and Management 40, 27-37.

Villar, E., Klopp, C., Noirot, C., Novaes, E., Kirst, M., Plomion, C., Gion, J.M., 2011: RNA-Seq reveals genotype-specific molecular responses to water deficit in Eucalyptus. BMC Genomics 12, 538 .

Wang, Y.C., Jiang, J., Zhao, X., Liu, G.F., Yang, C.P., Zhan, L.P., 2006: A novel LEA gene from Tamarix androssowii confers drought tolerance in transgenic tobacco. Plant Science 171, 655-662.

Warren, C.R., Aranda, I., Cano, F.J., 2011: Metabolomics demonstrates divergent responses of two Eucalyptus species to water stress. Metabolomics 8, 186-200.

Warren, C.R., Bleby, T.M., Adams, M.A., 2007: Changes in gas exchange versus leaf solutes as a means to cope with summer drought in Eucalyptus marginata. Oecologia 154, 1-10.

Weber, R.L.M., Wiebke-Strohm, B., Bredemeier, C., Margis-Pnheiro, M., Brito, G.G., Rechenmacher, C., Bertagnolli, P.F., de Sá M.E., Campos Mde, A., de Amorim, R.M., Beneventi, M.A., Margis, R., Grossi-de-Sa, M.F., Bodanese-Zanettini, M.H., 2014: Expression of an osmotin-like protein from Solanum nigrum confers drought tolerance in transgenic soybean. BMC Plant Biology 14, 343.

Wellstein, C., Poschlod, P., Gohlke, A., Chelli, S., Campetella, G., Rosbakh, S., Canullo. R., Kreyling, J., Jentsch, A., Beierkuhnlein, C., 2017: Effects of extreme drought on specific leaf area of grassland species: a meta-analysis of experimental studies in temperate and sub-Mediterranean systems. Global Change Biology 23, 2473-2481.

White, D.A., Beadle, C.L., Worledge, D., 1996: Leaf water relations of Eucalyptus globulus and E. nitens in seasonal, drought and species effects. Tree Physiology 16, 469-476.

White, D.A., Crombie, S.D., Kinal, J., Battaglia, M., McGrath, J.F., Mendham, D.S., Walker, S.N., 2009: Managing productivity and drought risk in Eucalyptus globulus plantations in south-western Australia. Forest Ecology and Management 259, 33-44.

White, D.A., McGrath, J.F., Ryan, M.G., Battaglia, M., Mendham, D.S., Kinal, J., Downes, G.M., Crombie, D.S., Hunt, M.E., 2014: Managing for water-use efficient wood production in Eucalyptus globulus plantations. Forest Ecology and Management 331, 272-280.

Yu, M.H., Ding, G.D., Gao, G.L., Zhao, Y.Y., Yan, L., Sai, K., 2015: Using plant temperature to evaluate the response of stomatal conductance to soil moisture deficit. Forests 6, 3748-3762. 